\title{
Adaptasi Sosial Mantan Narapidana dalam Perspektif Teori Aksi (Studi Kasus Mantan Narapidanana di Tengah Masyarakat Kecamatan Koto Baru Sungai Penuh Jambi)
}

\author{
Trizki Amelia ${ }^{1}$, Junaidi Junaidi ${ }^{2}$ \\ 1,2Universitas Negeri Padang \\ Email: trizkiamelia14@gmail.com, junaidiunp@ fis.unp.ac.id
}

\begin{abstract}
Abstrak
Penelitian ini dilatarbelakangi oleh banyaknya mantan narapidana yang hidup berdampingan dengan masyarakat di Wilayah Kecamatan Koto Baru, Sungai Penuh, Jambi. Dalam kasus adaptasi sosial mantan narapina dalam masyarakat khiusnya di Wilayah Kecamatan Koto Baru, Sungai Penuh, Jambi. Terungkap dalam beradaptasi dengan masyarakat setempat mantan narapina memilih tindakan yang dapat diterima oleh lingkungan mayasrakat untuk mencapai tujuannya yaitu kembali di tengah masyarakat. Penelitian ini dianalisis dengan tindakan sosial yang dikemukakan oleh Max Weber dan Tallcot Parsons. Teknik pemilihan informan dengan mengunakan teknik purposive sampling. Penelitian ini menggunakan pendekatan kualitatif studi kasus. Teknik pengumpulan data dilakukan dengan observasi, wawancara, dan dokumentasi yang dianalisis menggunakan teknik analisis Miles dan Huberman. Hasil penelitian di lapangan peneliti menemukan banyaknya mantan narapina di tengah masyarakat dalam beradaptasi melakukan tindakan sosial yang lebih aktif pada kegiatan masyarakat yaitu: (a) Gotong royong (b) menghadiri kenduri (c) mengikuti organisasi (d) pemenuhan kebutuhan hidup (5) mengikuti pengajian yang di adakan dalam masyarakat. Disamping itu masyarakat Wilayah Kecamatan Koto Baru menyoroti dari sudut pandang yang positif dari tingkah laku dan aktifitas seharihari dari mantan narapidana, masyarakat merangkul mantan narapina dalam berbagai kegiatan masyarakat yang ada untuk mengurangi rasa minder yang di alami oleh mantan narapidana.
\end{abstract}

Kata Kunci: Adaptasi, Mantan narapidana, Tindakan sosial

\begin{abstract}
This research is motivated by the large number of ex-convicts who live side by side with the community in the Koto Baru Sub-District Area, Sungai Penuh, Jambi. In the case of the social adaptation of ex-convicts in their particular communities in the Koto Baru District Area, Sungai Penuh, Jambi. It was revealed that in adapting to the local community, ex-convicts chose actions that were acceptable to the community environment to achieve their goal of being back in the community. This study was analyzed by social actions put forward by Max Weber and Tallcot Parsons. Informant selection technique using purposive sampling technique. This research uses a qualitative case study approach. Data collection techniques were carried out by observation, interviews, and documentation that were analyzed using Miles and Huberman analysis techniques. Research results in the field of researchers found that there were many ex-convicts in the community in adapting to do more active social actions in community activities, namely: (a) Mutual cooperation (b) attending festivity (c) following the organization (d) meeting the needs of life (5) following recitation held in the community. Besides that, the Koto Baru Subdistrict community highlighted from a positive point of view of the behavior and daily activities of ex-convicts, the community embraced ex-convicts in various existing community activities to reduce the inferiority experienced by ex-convicts.
\end{abstract}

Keywords: Adaptation, Former convicts, Social actions

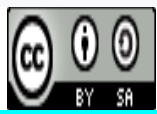

Received: August 6, 2019 Revised: August 10, 2019 Available Online: August 12, 2019 
Adaptasi merupakan penyesuain individu terhadap lingkungan dalam memenuhi kebutuhan hidup seperti kebutuhan psikologis, dorongan mantan narapina dan bisa beradaptasi kembali di tengah masyarakat (Gusef, 2011). Selain itu adaptasi merupakan proses penyesuaian diri dengan alam sekitarnya (Soerjono, 1986). Proses adaptasi merupakan sebuah proses penyesuaian diri atau berbaur kembali mantan narapidana di masyarakat setelah terlepas dari statusnya sebagai narapidana. Narapidana merupakan individu yang melakukan tindak kejahatan melanggar hukum dan norma di tengah masyarakat, sehingga individu tersebut dikenai hukuman oleh pengadilan (Zainul Akhyar, Harpani Matnuh 2014). Narapidana dalam masyarakat dianggap sebagai pembuat kerusuhan yang selalu mengganggu warga sehingga warga melakukan penolakan dan menjauhinya. Adaptasi sosial bagi mantan narapidana sangat penting, dimana orang yang pernah dihukum karena tindak kejahatan atau orang yang pernah menjadi tahanan akan memiliki perasaan negatif yang berlebihan terhadap dirinya sendiri karena mereka merasa bahwa masyarakat akan menilai mereka secara negatif. Realitanya mantan narapidana sering kesulitan kembali ke tengah masyarakat.

Narapidana dapat kembali ke tengah masyarakat apabila didukung oleh beberapa aspek dalam sarana ataupun prasarana yang lengkap. Tahanan perlu dididik dan diarahkan melalui proses pendidikan, dan diberdayakan dalam upaya rehabilitatif serta reintegrasi (Arif Wibawa, Yenni Sri Utami 2016). Narapidana yang sudah bebas dari jeruji besi tidak mudah untuk berdaptasi, bersosialisasi kembali dengan lingkungan setempat. Setelah bebaspun mantan narapidana tetap mendapatkan stigma negatif dari masyarakat karena tindak kejahatannya (Kurniawati, 2016). Kesusahan yang dirasakan mantan tahanan yaitu dalam meraih kembali keprcayaan dari warga setempat dan kesulitan dalam memenuhi kebutuhan hidup mereka. (Kartono, 1981)menyatakan bahwa mantan narapidana yang sudah keluar dari penjara pada umumnya menyesali masa lampau. Mereka ingin menebus dosa-dosanya di masa lampau dan mau memulai hidup yang baru. Mereka juga ingin memberikan partisipasi sosialnya, agar statusnya disamakan dengan anggota masyarakat lainnya. Harapannya mantan narapidana harus menunjukkan perubahan yang positif kepada masyarakat dengan cara bersikap lebih baik, sopan, rajin dalam beribadah, dan tidak segan membantu masyarakat lain. Mantan narapidana harus aktif pada acara-acara yang diadakan oleh masyarakat seperti melakukan gotong royong, ronda malam, ikut pada acara pengajian yang diadakan warga setempat dan acara lainnya.

Perubahan yang diharapkan di atas berlaku untuk seluruh mantan narapidana, termasuk juga mantan narapidana di Kecamatan Koto Baru, Sungai Penuh, Jambi. Jumlah mantan narapidana di Kecamatan Koto Baru cukup banyak. Hal ini dapat dilihat pada tabel berikut:

Tabel 1. Jumlah Mantan Narapidana di Kecamatan Koto Baru Kota Sungai Penuh Jambi

\begin{tabular}{cclll}
\hline No & Nama & \multicolumn{1}{c}{ Perkara } & \multicolumn{1}{c}{ Expsirasi } & \multicolumn{1}{c}{ Alamat } \\
\hline 1 & BA & UU No.22/2009 & $09-01-2014$ & Desa Kampung Tengah \\
\hline 2 & DP & Psl 363 KUHP & $21-03-2014$ & Desa Permai Indah \\
\hline 3 & IJ & UU No.23/2002 & $22-07-2014$ & Desa Dujung Sakti \\
\hline 4 & IA & UU No.23/2002 & $20-04-2015$ & Desa Dujung Sakti \\
\hline 5 & HM & Psl 170 KUHP & $05-02-2015$ & Desa Dujung Sakti \\
\hline 6 & MW & Psl 170 KUHP & $05-02-2015$ & Desa Dujung Sakti \\
\hline 7 & NR & Psl 351 KUHP & $10-10-2015$ & Desa Kampung Tengah \\
\hline 8 & SR & Psl 170 KUHP & $04-07-2016$ & Desa Koto Limau Manis \\
\hline 9 & ZT & Psl 170 KUHP & $04-07-2016$ & Desa Permai Indah \\
\hline 10 & ANA & Psl 170 KUHP & $04-07-2016$ & Desa Permai Indah \\
\hline
\end{tabular}


Trizki Amelia, Junaidi Junaidi Adaptasi Sosial Mantan Narapidana Dalam Perspektif Teori Aksi

\begin{tabular}{cclll}
\hline 11 & EW & Psl 170 KUHP & $04-07-2016$ & Desa Sri Menanti \\
\hline 12 & MD & Psl 363 KUHP & $21-01-2017$ & Desa Koto Baru \\
\hline 13 & WAP & UU No.23/2012 & $26-07-2017$ & Desa Koto Limau Manis \\
\hline 14 & ES & UU No.23/2012 & $26-07-2017$ & Desa Koto Limau Manis \\
\hline 15 & ZMP & UU No.23/2012 & $26-07-2017$ & Desa Koto Limau Manis \\
\hline 16 & BT & UU No.23/2012 & $26-07-2017$ & Desa Koto Limau Manis \\
\hline 17 & AWG & UU No.23/2012 & $25-08-2017$ & Desa Sri Menanti \\
\hline 18 & HJ & Psl 351 KUHP & $16-07-2018$ & Desa Permai Indah \\
\hline 19 & FA & Psl 363 KUHP & $29-10-2018$ & Desa Koto Baru \\
\hline 20 & AA & Psl 363 KUHP & & Desa Sri Menanti \\
\hline 21 & AS & Psl 363 KUHP & & Desa Koto Limau Manis \\
\hline 22 & ID & & & Desa Koto Baru \\
\hline 24 & FR & & & Desa Koto Baru \\
\hline 25 & AGS & & & Desa Koto Baru Koto Baru \\
\hline 26 & AM & & Desa Koto Baru \\
\hline 27 & HD & & Desa Koto Baru \\
\hline 28 & LK & & Desa Koto Baru Koto Baru \\
\hline 29 & AAK & & Desa Koto Limau Manis \\
\hline 30 & AIK & & Desa Sri Menanti \\
\hline 31 & NH & & & \\
\hline
\end{tabular}

Sumber: Data Rutan Negara Kelas II B Sungai Penuh dan Media Massa, 2019

Berdasarkan tabel 1 di atas dapat dilihat jumlah mantan narapidana di Kecamatan Koto Baru berjumlah 31 orang, mereka berasal dari beberapa desa di Kecamatan Koto Baru yang terdiri dari, Desa Koto Baru menempati angka tertinggi yaitu sebanyak 10 mantan narapidana, sedangkan angka terendah terdapat di Desa Kampung Tengah sebanyak 2 mantan narapidana.

Tanggapan negatif seperti stigma dari warga adalah wujud situasi yang mana kehadiran mantan tahanan tidak diharapkan oleh warga. Stigma adalh suatu situasi yang mana seseorang disingkirkan dari penerimaan sosialnya yang utuh. Untuk bisa menghilangkan stigma yang ada di masyarakat mantan narapidana melakukan permainan peran di masyarakat. Permainan peran dilakukan mantan tahanan agar warga bisa menerima mantan tahanan kehadirannya dalam masyarakat (Puspitasari, 2015). Mantan narapidana sesungguhnya memiliki hak untuk dapat kembali ke lingkungan tempat tinggal mereka dan memulai hidup baru yang lebih baik, namun stigma negatif menjadikan mereka merasa canggung untuk hidup bermasyarakat. Pada saat mantan tahanan beadaptasi dengan masyarakat lainnya, mantan tahanan beradaptasi berusaha menutupi masa lalunya dengan bersikap lebih positif, tapi pada saat mantan tahanan beradaptasi dengan sesame mereka yang pernah ditahan jeruji besi maka mereka akan bersikap terbuka apa adanya (Ardila, 2015). Sama halnya lembaga pemasyarakatan narapidana mebjalin interaksi sosial yang bersifat asosiatif dengan sesama narapidana (Silviani, 2017). Lebih parahnya lagi bukan hanya stigma yang diterima mantan narapidana tetapi juga ada perilaku deskriminatif dimana mantan narapidana kesulitan melakukan aktivitas, misalnya mantan narapidana sulit dalam mencari pekerjaan karena banyak perusahaan tidak mau memperkerjakan mantan narapidana sebagai karyawannya. Supaya mantan tahanan bisa beradaptasi dan bersosialisasi lagi dengan baik di lingkungannya, maka mantan tahanan harus bisa menjaga hubungan dengan cara pengungkapan diri (Ndoen, 2008).

Reaksi warga terhadap kriminalitas timbul karena adanya dorongan yang sifatnya emosional dari masyarakat tersebut, biasanya sifat tersebut dapat berkembang melalui 
bayangan tentang perilaku jahat yang dilakukan para penjahat. Pada saat itulah timbul perasaan benci terhadap perilaku tindak kriminal yang mana rasa benci merupakan wujud luapan emosi sesaat masyarakat kepada pelaku tindak kriminal yang bersifat emosional dan spontan. Masyarakat pada umumnya menganggap mereka sebagai pembuat kerusuhan yang membuat ketentraman kampung terganggu (Abdulsyani, 1987). Anggapan negatif dari warga pada mantan tahanan menimbulkan sikap pesimis bagi mantan tahanan. Sikap pesimis akan menimbulkan rasa minder bagi mantan tahanan untuk menjalani kehidupan dilingkungannya. Rasa tersebut juga membuat mantan tahanan kembali melakukan tindakan kejahatan karena mereka merasa dijauhi di lingkungannya (Nasriyah, 2017).

Berdasarkan studi awal yang peneliti lakukan terhadap mantan narapidana sebanyak sekian orang dari 31 orang, 20 dari 31 orang mereka sudah bisa melakukan adaptasi sosial. Hal ini antara lain dapat dilihat pada mantan narpidana IA yang bebas dari penjara dan melanjutkan hidupnya seperti masyarakat lain pada umumnya. IA ikut serta dalam kegiatan masyarakat seperti gotong royong, ikut menghadiri kenduri yang diadakan oleh masyarakat. IA juga menikah dengan orang yang tinggal di Kecamatan Koto Baru dan telah memiliki anak. Masyarakat sekitar sudah dapat menerima IA dan melibatkan IA dalam kegiatan yang diadakan oleh masyarakat di Wilayah Kecamatan Koto Baru.

Selanjutnya, hasil pengamatan peneliti terhadap mantan narapidana IJ. IJ menjadi terpidana ketika IJ masih menjadi pelajar di salah satu sekolah menegah atas di Kecamatan Koto Baru, setelah IJ menjalani masa hukumannya IJ kembali ke tengah masyarakat, IJ melanjutkan sekolahnya dan sekarang IJ melanjutkan pendidikannya di perguruan tinggi dan IJ termasuk mahasiswa yang aktif dalam berorganisasi di kampusnya yaitu organisasi HMI dan organisasi kumpulan mahasiswa yang ada di Kecamatan Koto Baru. IJ di tengah masyarakat seperti masyarakat lainnya juga melakukan sosialisasi dengan lingkungan sekitar, masyarakat sekitar sudah dapat menerima IJ di tengah masyarakat dan IJ juga terlihat memiliki banyak teman dalam berorganisasi maupun di saat IJ berada di tengah masyarakat.

Hasil pengamatan lainnya terhadap mantan narapidana ZT. ZT adalah seorang kepala keluarga didalam keluarga ZT diterima dan mendapatkan dukungan untuk kembali di tengah masyarakat, setelah bebas dari masa hukuman ZT membuka bisnis pasir di depan rumahnya. Bisnis pasirnya terbilang sukses karena cukup banyak pembeli apalagi pada saat banyaknya masyarakat yang membangun rumah dan membutuhkan pasir. ZT di terima di tengah masyarakat dibuktikan dengan ZT dilibatkan dalam kegiatan masyarakat dan masyarakat Kecamatan Koto Baru membantu untuk membeli pasir milik ZT.

EW mantan narapidana lainnya, setelah kembali di tengah masyarakat EW beraktivitas seperti masyarakat lainnya. Masyarakat menerima dan melibatkan EW dalam kegiatan mereka seperti EW ikut serta dalam petugas imam,bilal, dan penceramah bulan ramadhan masjid di tempat tinggalnya. EW juga menjadi timses politik dan ikut dalam kegiatan masyarakat lainnya.

Penelitian ini bertujuan untuk mendeskripsikan adaptasi sosial mantan narapidana di tengah masyarakat di Wilayah Kecamatan Koto Baru, Sungai Penuh, Jambi. Penelitian ini menggunakan teori Tindakan Sosial yang dikemukakan oleh Max Weber dan Talcot Parson. Berdasarkan asumsi yang dikemukakan oleh Weber di atas penelitian mengenai adaptasi sosial yang dilakukan mantan narapidana dengan lebih aktif mengikuti kegiatan masyarakat merupakan sebuah proses pilihan bagi seorang mantan narapidana dalam beradaptasi kembali di tengah masyarakat. Pilihan dalam beradaptasi kembali dengan lebih aktif mengikuti kegiatan masyarakat ini melibatkan proses pemikiran cara dan tujuan yang akan dicapai. Hal ini termasuk ke dalam tindakan sosial di mana tindakan seorang mantan narapidana memilih beradaptasi kembali dengan lebih aktif mengikuti kegiatan masyarakat sehingga mantan narapidana akan bertemu langsung, berinteraksi dengan masyarakat. 
Teori Aksi lainnya oleh Talcot Parson dapat dilihat bahwa aktor dalam penelitian ini adalah mantan narapidana yang memilih beradaptasi kembali dengan lebih aktif mengikuti kegiatan yang di adakan oleh. Melalui kegiatan masyarakat mantan narapidana akan bertemu langsung dan berinteraksi dengan masyarakat lainnya.

\section{Metode Penelitian}

Pendekatan pada penelitian ini adalah pendekatan kualitatif. Pendekatan kualitatif mencoba mengerti makna suatu kejadian atau peristiwa dengan mencoba berinteraksi dengan orang-orang dalam fenomena tersebut. Penelitian kualitatif merupakan suatu strategi inquiry yang menekankan pencarian makna, pengertian, konsep, gejala maupun deskripsi, menggunakan berbagai cara serta disajikan secara naratif. Penelitian kualitatif juga menggunakan natural setting yaitu keadaan atau latar alami, lingkungan dan sosial budaya sebagai sumber daya penelitian. Penelitian ini dilakukan di Kecamatan Koto Baru, Sungai Penuh, Jambi. Alasan peneliti memilih lokasi tersebut karena di Kecamatan Koto Baru terdapat realitas banyaknya mantan narapidana yang hidup berdampingan dengan masyarakat sekitar, maka daerah ini menjadi lokasi penelitian. Pemilihan informan dilakukan secara purposive sampling, yaitu penetapan informan penelitian secara sengaja sesuai dengan tujuan penelitian. Kriteria informan dalam penelitian ini yaitu orang-orang yang dipilih berdasarkan asumsi dan pengetahuan peneliti bahwa informan tersebut memiliki pengetahuan dan memberikan data mengenai resosialisasi mantan narapidana di tengah masyarakat Kecamatan Koto Baru, Kota Sungai Penuh, Jambi.

Adapun kriteria pemilihan dan subyek informan dalam penelitian ini adalah: (1) Mantan narapidana yang berdomisili di Kecamatan Koto Baru, (2) Keluarga dari mantan narapidana, (3) Masyarakat yang hidup berdampingan dengan mantan narapidana, dan (4) Tokoh masyarakat di Kecamatan Koto Baru. Teknik pengumpulan data merupakan langkah yang paling strategis dalam penelitrian, karena tujuan utama dari penelitian adalah mendapatkan data. Tanpa mengetahui teknik pengumpulan data, maka peneliti tidak akan mendapatkan data yang memenuhi standar data yang ditetapkan (Sugiyono, 2009). Data yang dikumpulkan dalam penelitian ini menggunakan teknik observasi partisipasi pasif, wawancara mendalam, dan studi dokumentasi.

Untuk memperoleh data yang abasah maka dilakukan dengan triangulasi data. Dalam teknik pengumpulan data, triangulasi merupakan teknik pengumpulan data yang menggabungkan berbagai teknik pengumpulan data dan sumber data yang telah ada. Dengan menggunakan teknik triangulasi data, maka data yang diperoleh akan lebih konsisten, tuntas dan pasti (Sugiyono, 2009). Dalam penelitian kualitatif, analisis data bersifat terbuka dan fleksibel disesuaikan dengan data yang didapatkan dilapangan. Data-data yang diperoleh di lapangan dalam penelitian ini diolah menggunakan teknik Interaktif model of analysis yang terdiri dari tiga tahap yaitu reduksi data, penyajian data dan verifikasi data (B. Miles, Matthew 1984).

\section{Hasil dan Pembahasan}

Dalam kasus adaptasi sosial mantan narapidana di tengah masyarakat, khususnya di Wilayah Kecamatan Koto Baru, Sungai Penuh, Jambi. Terungkap dalam beradaptasi dengan masyarakat setempat mantan narapidana memilih tindakan yang dapat di terima oleh lingkungan masyarakat untuk mencapai tujuannya yaitu kembali di tengah masyarakat. 


\section{Mantan Narapidana di Tengah Masyarakat}

Banyak orang berpendapat bahwa mantan narapidana merupakan seseorang yang sangat buruk. Mantan narapidana di tengah masyarakat mengalami kesulitan dalam beradaptasi dan berinteraksi kembali dengan masyarakat. Adaptasi yang dilakukan mantan narapidana dimaksudkan untuk mendapatkan kepercayaan kembali pada masyarakat. Namun kenyataan hidup membuktikan tujuan hidup di atas tidak lah mudah untuk dicapai, bahkan mantan narapidana mendapatkan kesulitan untuk kembali ke tengah masyarakat bukan hanya kesulitan yang di dapatkan dalam diri mantan narapidana sendiri namun kesulitan dari masyarakat karena adanya stigma negatif dari masyarakat terhadap mantan narapidana. Tanggapan warga terhadap mantan tahanan terkadang berlebihan, sehingga mempengaruhi anggapan para mantan tahanan terhadap diri mereka. Mantan tahanan mengalami diskriminasi sosial, sehingga mereka sulit memperoleh kerja yang baik. Mantan tahanan tidak dapat meningkatkan status kedudukan dan melakukan mobilitas vertical (Hanun, 2013).

Mantan narapidana yang telah kembali ke tengah masyarakat harus dapat menimbulkan semangat pada dirinya sendiri dengan suatu harapan yang bersifat membangun untuk kembali hidup ke masyarakat lagi. Tidak banyak mantan narapidana yang mampu melakukan hal tersebut karena kurang percaya diri dan ada rasa minder untuk kembali berbaur dengan masyarakat, kemudian masyarakat yang tidak mau menerima keberadaan dari mantan narapidana.

Hal ini berdasarkan hasil wawancara yang dilakukan dengan Pak Amra yang bekerja di Rutan Negara Kelas II B Sungai Penuh sebagai Kepala Kasubsi Pelayanan Tahanan. Ia menuturkan bahwa;

“...masyarakat akan sulit menerima mantan narapidana yang kembali

ke tengah masyarakat karena tindak kejahatan yang mereka lakukan

kemudian adanya ketidakpercayaan dan kekhawatiran masyarakat hidup berdampingan dengan mantan narapidana"

Dalam kenyataan di masyarakat, masih banyak masyarakat yang mau menerima dan merangkul mereka dalam berbagai kegiatan desa yang ada untuk mengurangi rasa minder yang dialami oleh mantan narapidana tersebut khususnya di Wilayah Kecamatan Koto Baru. Kegiatan desa merupakan suatu tindakan sosial mantan narapidana dalam beradaptasi dengan masyarakat. Tindakan sosial tersebut merupakan alternatif cara adaptasi yang di tempuh oleh mantan narapidana di Kecamatan Koto Baru dalam beradaptasi kembali di tengah masyarakat. Dalam teori Talcot Parson ia menyatakan bahwa aktorlah yang menetukan cara untuk mencapai tujuan. Pilihan yang dianggap mantan narapidana adalah cara yang sesuai dengan kondisi lingkungan masyarakat.

Berdasarkan wawancara diatas dapat di ketahui bahwa cukup banyak mantan narapidana yang hidup berdampingan dengan masyarakat khusunya di Wilayah Kecamatan Koto Baru. Hal ini diungkapkan juga oleh pak Tajzi (56 tahun) yang bekerja di Kantor Camat Kecamatan Koto Baru dan berdomisili di Kecamatan Koto Baru. Ia mengungkapkan bahwa:

“...Meneng lah banyiak uhoa yang masuk penjariu, banyiak ugiu angih kaluwoa karnu kitao kutu bahiu lah adiu tau tentang hukum idiak srupao duliu kalu duliu adiu masalah masyarakat seneng di slesea dengan duduk adat tapi meneng uhoa banyiak yang langsong melapor kik polisi"

Artinya, 
“...sekarang sudah banyak yang masuk penjara, banyak juga yang keluar dari penjara karena masyarakat Kecamatan Koto Baru sudah banyak tahu tentang hukum tidak sama seperti dulu kalau ada masalah masyarakat menyelesaikannya dengan duduk adat tapi sekarang masyarakat langsung melaporkan ke pihak yang berwajib atau polisi.

Berdasarkan hasil dari beberapa wawancara di atas dapat dilihat bahwa terdapat banyak mantan narapidana yang hidup berdampingan dengan masyarakat, mereka dalam beradaptasi dan berinteraksi dengan masyarakat memilih tindakan sosial seperti mengikuti kegiatan yang diadakan oleh masyarakat. Mantan narapidana banyak yang sudah bisa beradaptasi di tengah masyarakat, begitu juga dengan masyarakat sudah bisa menerima dan merangkul mereka dalam berbagai kegiatan masyarakat.

\section{Tindakan Sosial Mantan Narapidana dalam Beradaptasi di Tengah Masyarakat}

\section{Gotong Royong}

Mantan narapidana di tengah masyarakat dalam melakukan adaptasi sosial dengan ikut kegiatan gotong royong, gotong royong adalah suatu kegiatan dimana masyarakat berkumpul dan mengerjakan pekerjaan secara bersama-sama agar pekerjaan tersebut bisa terselesaikan dengan baik. Begitu pun mantan narapidana melakukan interaksi sosial berupa gotong royong untuk menjaga kebersihan lingkungan tempat tinggalnya. Mantan narapidana memilih alternatif cara untuk mencapai tujuan dengan ikut serta bergotong royong bersama masyarakat agar dapat beradaptasi kembali di tengah masyarakat. Hal ini diungkapkan oleh DP (46 tahun) bahwa:

“...satiangk uhoa ngnoak bakumpaoh mersih mesjongk, mersih parit kamuku umoah pukuk mersih kecamatan kutu bahiu. Akau, insya allah adiu bwea samao biasunyu diomong kik mesjongk untuk bakumpaoh, kadia kalu sidik tedengia uhoa ngomong kik mesjongk uhoa kamuku eneh ngimbu lalau sempoak"

Artinya:

“...setiap masyarakat mengadakan perkumpulan untuk bergotong royong membersihkan mesjid, membersihkan selokan di sekitar tempat tinggal saya. Saya insya allah ada ikut serta, biasanya di umumkan di mesjid untuk berkumpul, kadang kalau tidak terdengar pengumumannya saya di panggil oleh tetangga depan rumah untuk ikut bergotong royong.

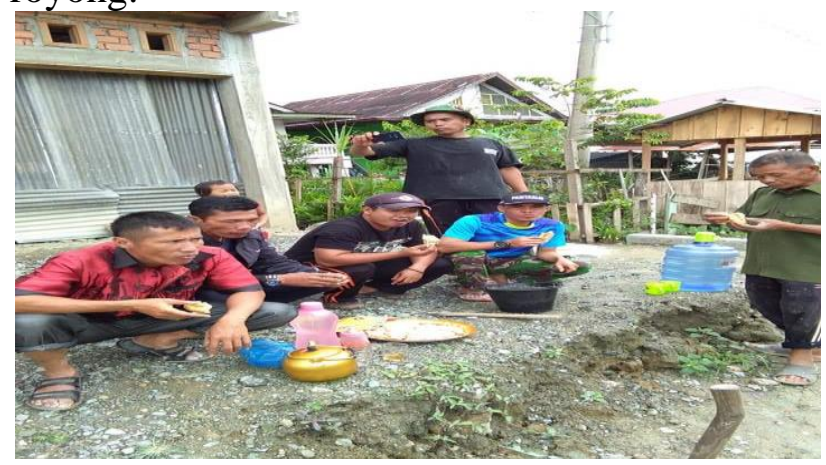

Gambar 1. DP yang sedang berinteraksi dan ikut membantu masyarakat memperbaiki jalan. 
Hal tersebut juga di perkuat oleh observasi yang penulis lakukan pada tanggal 21 juni 2019 sekitar pukul 08.15 WIB ketika penulis sedang wawancara dengan salah satu staf desa Permai Indah Pak Erwin (29 tahun). Ia memberitahukan kepada penulis bahwa dua orang lakilaki yang membawa cangkul dan sedang ikut meperbaiki jalan bersama masyarakat tersebut adalah mantan narapidana. Penulis mengamati mantan narapidana tersebut sedang berinteraksi dengan masyarakat lainnya.

Adaptasi sosial mantan narapidana diatas terlihat memilih tindakan sosial berupa gotong royong. Gotong royong yang dilakukan oleh mantan narapidana seperti kerjasama memperbaiki jalan, membersihkan selokan dan bersama menjaga lingkungan tempat tinggalnya tanpa merasa terbebani karena mereka menyadari hal tersebut telah menjadi tanggung jawab mereka.

\section{Menghadiri Kenduri yang Diadakan Masyarakat}

Dalam menjalani keseharian hidup berdampingan dengan masyarakat mantan narapidana melanjutkan hidupnya seperti masyarakat lain pada umumnya. Mantan narpidana di Wilayah Kecamatan Koto Baru mereka dalam beradaptasi dengan masyarakat juga mealakukan hal yang biasa dilakukan oleh masyarakat seperti ikut menghadiri kenduri yang diadakan oleh masyarakat.

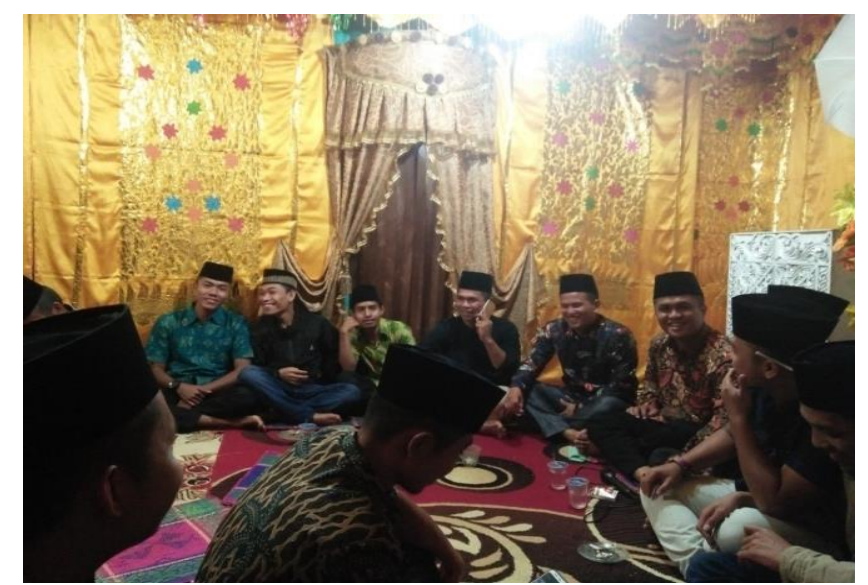

\section{Gambar 2. Mantan Narapidana IA Menghadiri Kenduri}

\section{Mengikuti Organisasi}

Organisasi merupakan sebuah wadah atau tempat berkumpulnya sekelompok orang yang bekerjasama untuk mencapai tujuan tertentu, manusia berorganisasi untuk menghemat waktu, menambah teman, menambah wawasan dan hal lainnya. Mantan narapidana beradaptasi sosial dengan masyarakat dengan mengikuti organisasi yang ada di tengah masyarakat sehingga mantan narapidana dapat melakukan sosialisasi dan berinteraksi dengan masyarakat.

\section{Pemenuhan Kebutuhan Hidup}

Dalam memenuhi kebutuhan sehari-hari, individu harus bekerja agar dapat terpenuhi segala kebutuhan hidupnya. Mantan narapidana maupun masyarakat, mereka saling membutuhkan karena mantan narapidana juga bagian dari masyarakat. Oleh kareana itu mereka selalu membutuhkan orang lain. 
Trizki Amelia, Junaidi Junaidi Adaptasi Sosial Mantan Narapidana Dalam Perspektif Teori Aksi

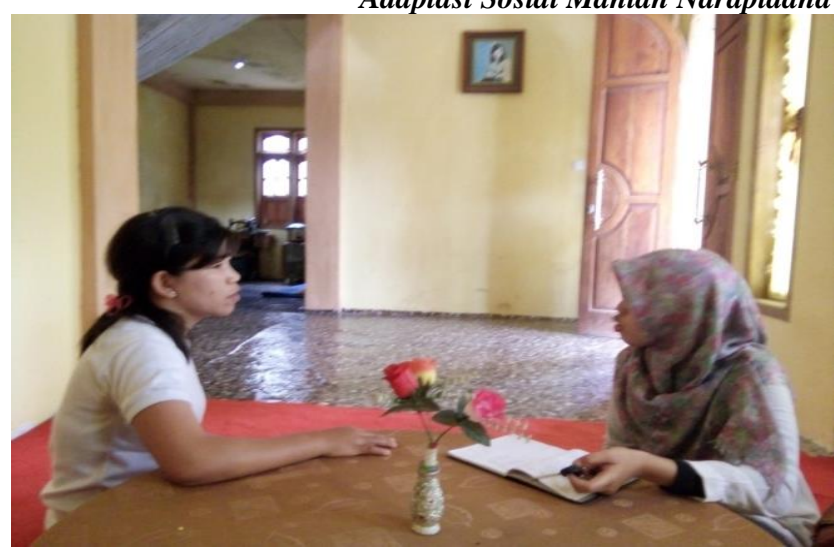

\section{Gambar 3. Yang Memperkerjakan dan Membantu Mantan Narapidana}

Hal ini senada dengan yang di sampaikan oleh Ibuk Yesi (40 tahun) yang memiliki warung di Wilayah Kecamatan Koto Baru. Berdasarkan wawancara di atas dapat diketahui bahwa masyarakat sudah bisa menerima keberadaan dari mantan narapidana dan membantu mantan narapidana tersebut dengan mempekerjakan dan memberikan gaji untuk memenuhi kebutuhan hidup mantan narapidana tersebut.

\section{Mengikuti Pengajian yang Diadakan oleh Masyarakat}

Masyarakat Kecamatan Koto Baru setiap desa membuat kelompok pengajian, kelompok pengajian ini di buat selain untuk belajar mengaji bagi yang kurang lancar tapi juga untuk berkumpul membuat uang kas untuk segala macam yang berhubungan dengan keuangan yang dapat di tanggulangi dengan adanya uang kas. Kegiatan ini diadakan pada malam hari tempat pengajiannya secara bergantian di rumah masing-masing anggota. Anggotanya siapa pun boleh diikut sertakan, hal ini di ungkapkan oleh Bapak Ali (41 tahun). Ia mengungkapkan bahwa:

“...kelompok pengajian eneh untuk bakumpaoh-kumpaoh balajia ngajui ngi kurang lancoa ngajui, anggotanyu bapak-bapak loah kegiatannyu maloa ahai sudiah isyoa tempik nyu begantui setiangk umah anggota. Anggota sapu pun boloeh samao EW adiu ugiu samao nyu termasuk uhoa yang aktif manju seneng. Adiu acara kik mesjong nyu lalau pengajian eneh nyu termasuk ugiu uhoa ngi rajin lalau senu kegiatan kik mesjong bahu tegeng puasu eneh nyu jadi petugas imam, bilal, ngi penceramah bulan ramadhan kik mesjongk seneng",

Artinya:

“...kelompok pengajian ini untuk ngumpul-ngumpul belajar ngaji bagi yang kurang lancar ngaji, anggotanyu bapak-bapak saja, kegiatannya pada malam hari setelah shalat isya tempatnya bergantian setiap rumah anggota. Anggotanya siapapun boleh ikut mantan narapidana EW juga ikutserta EW juga termasuk orang yang aktif dalam kegiatan masyarakat sekitar sini. Pengajian juga EW termasuk orang yang rajin seperti kegiatan di mesjid EW juga jadi petugas imam, bilal, dan penceramah bulan ramadhan di masjid sini” 
Trizki Amelia, Junaidi Junaidi

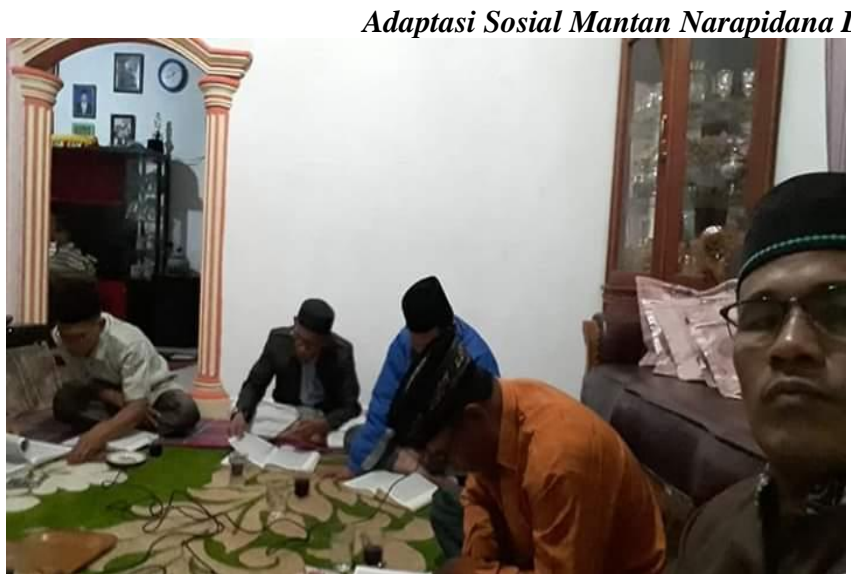

Gambar 4. EW sedang mengikuti kelompok pengajian

\section{Pandangan masyarakat terhadap mantan narapidana di Kecamatan Koto Baru}

Berdasarkan pengamatan penulis tentang adaptasi sosial terhadap narapidana yang telah bebas dari Rumah Tahanan untuk kembali ke dalam masyarakat di Kecamatan Koto Baru, Sungai Penuh, Jambi, bahwa kenyataannya sesuai dengan harapan, karena di Wilayah tersebut masyarakat sudah bisa menerima keberadaan mantan narapidana. Masyarakat di Wilayah Kecamatan Koto Baru menyoroti dari sudut pandang yang positif dari tingkah laku dan aktivitas sehari-hari dari mantan narapidana, masyarakat merangkul mantan narapidana dalam berbagai kegiatan masyarakat yang ada untuk mengurangi rasa minder yang dialami oleh mantan narapidana tersebut.

\section{Penutup}

Memang sulit bagi individu yang menyandang status sebagai mantan narapidana untuk kembali berbaur dengan masyarakat. Untuk dapat mengubah pandangan masyarakat terhadap diri mereka, mantan narapidana harus menunjukkan perubahan yang positif kepada masyarakat dengan bersikap lebih baik, sopan, rajin dalam beribadah dan tidak enggan-enggan membantu masyarakat lain. Pada acara-acara yang diadakan oleh masyarakat mantan narapidana lebih aktif dari pada warga lain seperti: gotong royong, mengahdiri kenduri, mengikuti organisasi, ikut pada acara pengajian yang diadakan warga setempat dan acara lainnya.

Untuk memenuhi kebutuhan hidup sehari-hari, individu harus bekerja agar dapat terpenuhi segala kebutuhan hidupnya. Mantan narapidana lebih membuat lapangan pekerjaan sendiri dalam pemenuhan kebutuhan sehari hari, seperti bertani, membuka usaha travel, usaha pasir, dan hal lainnya. Pandangan masyarakat menyoroti dari sudut pandang yang positf mau menerima keberadaan narapidana yang telah bebas dari rumah tahanan. Masyarakat merangkul mereka dalam berbagai kegiatan desa yang ada untuk mengurangi rasa minder yang dialami oleh mantan narapidana. Masyarakat memebantu narapidana dan memakai jasa dari mantan narapidana seperti menerima mantan narapidana untuk kerja membantu pekerjaan rumah, membantu membeli usaha pasir milik mantan narapidana.

Mantan narapidana yang memilih lebih aktif untuk mengikuti kegiatan masyarakat dalam beradaptasi kembali di tengah masyarakat karena mantan narapidana akan bersosialisasi dan berinteraksi langsung dengan masyarakat dengan begitu masyarakat akan melihat perubahan yang positif dari mantan narapidana. 
Abdulsyani, Drs. 1987. Sosiologi Kriminalitas. Bandung: CV Remadja Karya.

Ardila, Ditta Wini. 2015. "Pola Interaksi Mantan Narapidana Dengan Lingkungan Masyarakat Di Kelurahan Prawirodirjan, Kecamatan Gandoman, Yogyakarta." Yogyakarta: UINSKY.

Arif Wibawa, Yenni Sri Utami, dan Siti Fatonah. 2016. "Pola Komunikasi Konselor Dan Narapidana." Yogyakarta: UPN.

B. Miles, Matthew, A. Michael Huberman. 1984. Qualitative Data Analysis. America: Second Printing.

Gusef, Yolla. 2011. “Adaptasi Kehidupan Sosial Mantan Narapidana Dalam Masyarakat." Padang: Universitas Andalas.

Hanun, Isna Busyrah. 2013. "Studi Tentang Penyesuaian Diri Mantan Narapidana Di Kecamatan Banjarnegara Kabupaten Banjarnegara." Yogyakarta: Universitas Negeri Yogyakarta.

Kartono, Kartini. 1981. Patologi Sosial. Jakarta: Raja Grafindo Persada.

Kurniawati, Dwi Ayu. 2016. "Stigma Sebagai Suatu Ketidakadilan Pada Mantan Narapidana Perempuan Di Masyarakat Surabaya.” Surabaya: Universitas Airlangga.

Nasriyah. 2017. "Label Pada Mantan Narapidana Di Desa Air Lengit Kecamatan Bunguran Tengah Kabupaten Natuna.” Tanjung Pinang: Universitas Maritim Raja Ali Haji.

Ndoen, Leonie Fitriani. 2008. "Pengungkapan Diri Pada Mantan Narapidana." Depok: Universitas Gunadarma.

Puspitasari, Vitriana Mei. 2015. "Strategi Adaptasi Mantan Narapidana Di Masyarakat (Studi Deskriptif Tentang Konsep Diri Dan Strategi Adaptasi Mantan Narapidana Terhadap Stigma Yang Ada Di Masyarakat).” Surabaya: Universitas Airlangga.

Silviani, Sindi. 2017. "Bentuk Interaksi Sosial Narapidana Perempuan Di Lembaga Pembinaan Khusus Anak Kelas II B Tanjung Pati Kabupaten Lima Puluh Kota.” Padang: UNP.

Soerjono, Soekanto. 1986. Pengantar Penelitian Hukum Cet Ke-3. Jakarta: UI Press.

Sugiyono. 2009. Metode Penelitian Kualitatif $R \&$ D. Bandung: Alfabet.

Zainul Akhyar, Harpani Matnuh, Muhammad Najibuddin. 2014. "Persepsi Masyarakat Terhadap Mantan Narapidana Di Desa Benua Jingah Kecamatan Barabai Kabupaten Hulu Sungai Tengah.” Banjarmasin: Universitas Lambung Mangkurat. 